\title{
Üniversite Öğrencilerinin Geleceğe Yönelik Tutum ve Olumlu Gelecek Beklentilerinin Psikolojik İyilik Halleri Üzerindeki Etkisi
}

\author{
The Impact of University Students' Future Attitudes and Postive Future \\ Expectations on Psychological Wellness Situations
}

\author{
V. Rüya EHTIYAR * \\ Aslı ERSOY ** \\ Abdullah AKGÜN ${ }^{* * * *}$ \\ Ebru KARAPINAR ****
}

$\ddot{O}_{z}:$ Bu çalışmada, üniversite öğrencilerinin geleceğe ilişkin yönelim örüntülerinin saptanması ve geleceğe ilişkin yönelimlerinin psikolojik iyilik hallerini ne oranda etkilendiğinin belirlenmesi amaçlanmaktadır. Araştırma, Akdeniz Üniversitesi Turizm Fakültesi'nde öğrenim gören ve kolayda örnekleme yöntemi ile seçilen 807 öğrenci üzerinde gerçekleștirilmiştir. Araştırmada öğrencilerin psikolojik iyilik hali düzeylerini belirlemek amacıyla Diener ve diğerleri (2010) tarafindan geliştirilen ve Fidan ve Usta (2013) tarafindan Türkçe'ye çevrilen İyilik Hali Ölçeği (İHÖ) kullanılmıştır. Öğrencilerin geleceğe ilişkin yönelimlerinin belirlenmesinde ise İmamoğlu (2001) tarafindan geliştirilen Geleceğe Yönelik Tutum ile Olumlu Gelecek Beklentisi Ölçeği kullanılmıştır. Anket formu ile toplanan verilerin analizinde güvenilirlik, frekans, korelasyon ve basit doğrusal regresyon analizi kullanılmıştır. Elde edilen sonuçlar üniversite öğrencilerinin geleceğe yönelik tutum ve olumlu gelecek beklentileri ile öğrencilerin psikolojik iyilik hali arasında anlamlı bir ilişki bulunduğunu ve olumlu gelecek beklentisinin geleceğe yönelik tutuma oranla psikolojik iyilik halini daha çok etkilediğini göstermektedir. Araştırma, üniversite öğrencilerinin geleceğe yönelik tutum ve olumlu gelecek beklentileri ile psikolojik iyilik hali arasındaki ilişkiyi ortaya koyması bakımından ve de bu doğrultuda koruyucu/önleyici ve geliştirici programların hazırlanmasında yararlanılabilecek bir bilgi kaynağı olması bakımından önem kazanmaktadır.

Anahtar sözcükler: Geleceğe Yönelik Tutum, Olumlu Gelecek Beklentisi, Psikolojik İyilik Hali, Turizm

Abstract: The aim of this study was to determine the orientation patterns of university students to the future and to determine the way in which the psychological wellbeing of future orientations are affected. The research sample consisted of 807 students at the Faculty of Tourism at Akdeniz University selected through convenience sampling. In order to determine the wellbeing of the students in the survey, The Wellness Evaluation of Lifestyle Scale-Turkish Form (IHÖ) developed by Diener and others (2010) and translated from English into Turkish by Fidan and Usta (2013) was employed. In determining the future orientations of these students the Attitudes toward the Future Scale and Positive Future Expectations Scale developed by İmamoğlu (2001) was employed. Reliability, frequency, correlation and simple linear regression analysis were used in the analysis of the collected data from the questionnaire form. The results show that there is a meaningful relationship between the attitude toward the future and positive future expectations and a students' psychological wellbeing and that positive future expectations influence wellbeing more than attitudes toward the future. This research is important in terms of university students' orientation towards the future and its relationship with students' psychological wellbeing and provides a source of information that can be used in the preparation of preventive and development programs in this respect.

Keywords: Future-Oriented Attitude, Positive Future Expectations, Psychological Wellbeing, Tourism

* Doç. Dr., Akdeniz Üniversitesi, Turizm Fakültesi, Antalya. ehtiyar@akdeniz.edu.tr

** Arş. Gör., Akdeniz Üniversitesi, Turizm Fakültesi, Antalya. asliersoy@akdeniz.edu.tr

*** Öğr. Gör., Akdeniz Üniversitesi, Turizm Fakültesi, Antalya. akgun@akdeniz.edu.tr

***** Öğr. Gör., Ondokuz Mayıs Üniversitesi, Samsun. ebru.karapinar@omu.edu.tr 


\section{Giriş}

Psikoloji bilimi tarihsel gelişim süreci içinde sorun odaklı yaklaşımlar yerine bireylerin güçlü yönlerine ve iyilik haline (wellness) önem veren bir anlayışa doğru kaymıştır (Diener 2000). Bu anlayış insanın olumsuz ve zayıf yönlerine odaklanan modernizm etkisindeki problem çözmeye yönelik psikolojiye karşılık, pozitif psikolojinin koruyucu/önleyici doğasıyla kişinin olumlu ve güçlü yönlerine odaklanmaktadır (Karaırmak \& Siviş 2008, 102). Özellikle son on yılda zihinsel ve fiziksel rahatsızlıkların tedavisinde geleneksel, hastalık temelli tıbbi modele alternatif olarak yeni bir iyilik bakış açısı ortaya çıkmıştır (Myers, Sweeney \& Witmer 2000, 251). Alan yazında da giderek artan şekilde turizm akademisyenlerinin araştırmalarını pozitif psikoloji üzerine gerçekleştirdiği gözlemlenmekte ve insan ilişkilerinin iyilik hali üzerindeki kritik rolünü vurgulamaktadır (Filep 2016, 113). İyilik hali kavramı sağlıklı olmaktan çok farklı bir anlama gelmektedir. Sağlıklı olma, bireyin kendi çevresi ile barış içinde olduğu nispeten pasif bir hastalık hali olarak var olabilir. İyi oluş, bireyin ileriye doğru yol aldığı, daha yüksek bir işleyiş potansiyeline erişeceği bir değişim şartı olarak kavramsallaştırılmaktadır. Birey için yüksek düzeyde iyilik hali bireyin potansiyelini en üst düzeye çıkarmak için yönlendirilmiş entegre bir çalışma yöntemi olarak tanımlanmaktadır (Dunn 1959, 447). Bu tanımlamaya benzer şekilde Ryan ve Deci $(2001,142)$ iyilik halini kişi için en uygun olan psikolojik işlev ve deneyim olarak ifade etmektedir.

Bilindiği üzere gençlik insan hayatının kuşkusuz en önemli ve etkin bir dönemini ifade etmektedir. Özellikle üniversite ortamı, stres ve kaygı yaratan koşulları bünyesinde barındırmaktadır. Bununla birlikte üniversite yılları, birçok yaşam biçimi kararının alındığı gençlik, kimlik kazanımı, bunalımlar, ani değişiklikler ve kararsızlıklar yaşandığı zaman dilimidir. Bu açıdan bakıldığında bir olgu olarak gençlik ve onun sorunların gözlenmesi olağandır. Kasapoğlu $(2014,274)$ da bu dönemde öğrencilerin bedensel, ruhsal ve sosyal yönden daha sağlıklı bir yaşam biçimi geliştirmelerine yardımcı olmak içinönleyici programların hazırlanarak, uygulanmasının önemli olduğunu vurgulamaktadır. Benzer şekilde turizm eğitimi alan öğrenciler üzerine gerçekleştirilen bir çok görgül çalışmada da sosyal ve psikolojik sorunların fazlalaştığ görülmektedir Turizm öğrencileri üzerine gerçekleştirilen bir çok görgül çalışmada da sosyal ve psikolojik sorunların fazlalaştığ göstermektedir (Pavesic \& Brymer 1990; Baron \& Maxwell 1993; Getz 1994; Altman \& Brothers 1995; Kızılırmak 2000; Kuşluvan \& Kuşluvan 2000; Kozak \& Kizılırmak 2001; Aksu \& Köksal 2005).

Buradan hareketle bu çalışmada; turizm fakültesi öğrencilerinin psikolojik iyilik hallerini yordayan değişkenler üzerine durulmuştur. Bu değişkenler; geleceğe ait tutum ve olumlu gelecek beklentisidir. İmamoğlu ve Güler-Edwards $(2007,117)$ geleceğe umutla, iyimser olarak yönelen bir kişinin amaçlarına ulaşmak için daha olumlu olacağı, ısrarcı bir çaba göstereceği ve kolay pes etmeyeceğini belirtmektedir. Eryılmaz $(2011,210)$ da benzer şekilde olumlu gelecek yönelimine sahip olan bireyler gelecek konusunda iyimser ve umutludurlar, olumsuz gelecek yönelimine sahip olan bireylerle kıyaslandığında bu bireylerin gelecekteki amaçlarına ulaşmak için çaba gösterdiklerini ileri sürmektedir. Bu nedenle bu çalışmada "Üniversite ögrrencilerinin geleceğe yönelik tutum ve olumlu gelecek beklentileri psikolojik iyilik hallerini yordamakta midır?" sorusuna yanit aranacaktır.

Bu bağlamda ilk olarak ilgili yazına ait bir özet sunulmuştur. İzleyen bölümlerde araştırma yöntemi açıklanarak elde edilen sonuçlar tartışılmıştır. Son olarak çalışmanın başlıca kısıtları ve ileride yapılabilecek araştırmalara dair bazı önerilerde bulunulmuştur. 


\section{Psikolojik İyilik Hali ve Geleceğe Yönelik Tutum ve Beklentiler}

Alan yazında iyilik hali kavramını inceleyen hedonia (öznel iyilik hali) ve eudaimonia (psikolojik iyilik hali) olmak üzere iki görüş vardır. Hedonia ve eudaimonia kavramları, hem geleneksel hem de güncel görüşlere göre bireylerin iyilik hallerine ilişkin genellikle karşıt görüşler olarak bir araya getirilmiştir (Ryan, Huta \& Deci 2008, 139). Öznel iyilik hali, sosyal değişimi izlemek ve sosyal politikayı geliştirmek üzere yaşam kalitesinin faydalı göstergelerini araştırmak için 1950'lerin sonlarında ortaya çıkmıştır. Temeli bireyin zorluklarla karşılaştığında kendini gerçekleştirmesini ve anlamlı bir yaşam için bireyin potansiyelini vurgulayan daha önceki klinik veyetişkin gelişim psikolojisi teorilerine dayanan psikolojik iyilik hali kavramı ise 1980'li yıllarda amprik çalışmalarla başlamıştır. Öznel iyilik hali geleneği iyilik halini yaşam doyumu ve mutluluk açısından açıklarken, psikolojik iyilik haligeleneği insan gelişiminin ve yaşamın varoluşsal zorluklarının oluşumlarına büyük önem vermektedir (Keyes, Shmotkin \& Ryff 2002). Kısaca, hedonik yaklaşım (öznel iyilik hali) öznel olarak belirlenmiş olumlu zihinsel durumlara odaklanırken, eudaimonic yaklaşım (psikolojik iyilik hali) ise birey için iyi olan deneyimler üzerine odaklanmaktadır (Kagan 1992, 169).

Psikolojik iyilik hali yazında oldukça önemli görülen konulardan birisidir. Psikolojik anlamda iyilik hali sıkıntı veya diğer zihinsel sorunların olmamasından daha fazlasını ifade etmektedir. Zira psikolojik iyilik hali, bir bireyin olumlu benlik saygısı, ustalık, özerklik, başkalarıyla olumlu ilişkiler geliştirme, hayatta bir amaca sahip olma ve anlam duygusu ve devam eden büyüme ve gelişme hislerine sahip olmasını ifade etmektedir (Ryff 1995, 103). Psikolojik işlevsellik bakış açısına dayanan psikolojik iyilik hali, yaşamı tam ve son derece tatmin edici bir şekilde yaşamaya odaklanmaktadır (Deci \& Ryan 2008, 1). Aslında psikolojik iyilik halinin anahtar kavramları, insan gelişiminin öne çıkan görev ve zorluklarına, kendini gerçekleştirmeye, olgunlaşmaya, tam işlevsellik ya da bireyselleşmenin ne olduğunu ortaya koyan klinik bilgilere ve zihinsel sağlığın olumlu kriterlerinin belirleyicilerine dayanan yaşam boyu gelişim kuramlarından üretilmiştir (Ryff et al. 1999, 248). Görüldüğü üzere bireyin kendini gerçekleştirmesi ve mutlu bir hayata sahip olması psikolojik iyilik hali için oldukça önemlidir. Farklı bakış açıları ile açıklanmaya çalışılan psikolojik iyilik hali kavramının bu araştırmadaki teorik dayanağı ise Diener ve diğerlerinin (2010) geliştirmiş olduğu psikolojik iyilik hali modeline dayanmaktadır. Araştırmacılar psikolojik iyilik halini sekiz madde ile açıklamış ve buna yönelik bir ölçek geliştirmiştir. Kavramı açıklayan söz konusu maddeler ise olumlu ilişkilerden yeterlik hislerine, yaşam amacı, sosyal ilişkiler, anlamlı ve amaçlı bir yaşama sahip olmaya kadar insan fonksiyonunun önemli öğelerini tanımlamaktadır.

İyilik halini betimleyen araştırmacılar bu kavramla ilişkili çok sayıda değişkenden söz etmiştir. Olumlu ve olumsuz duygulanımın etkileri (Bradburn 1969), olumlu duygulanım ve mutluluk (Lawton 1983), yaşam tamini, öz-kabul ve hakimiyet (Ryan \& Deci 2001), yaş (Khumalo, Termane \& Wissing 2012), öz sayg1 (Betton 2001), medeni durum (Kim \& McKenry 2002), gelir düzeyi (Braun 1976), stres (Srimathi \& Kiran 2010), egzersiz (Scully et al. 1998), inanç (Francis \& Kaldor 2002) iyilik haliile ilgili olan değişkenlerden bazılarıdır. Bu çerçevede öğrencilerin algılamalarını ölçen belli başlı görgül çalışma örneklerine de yer verilebilir. Bunlar arasında; sosyal destek (Granello 1999), cinsiyet (Cenkseven \& Akbaş 2004; Gürel 2009; Perez 2012), yaşam doyumu (Şeker \& Akman 2015), yalnızlık (Çeçen \& Cenkseven 2007), duygusal farkındalık (Kuyumcu \& Güven 2012), kişilik ve öz-anlayış (Sarıcaoğlu \& Arslan 2013) olarak sıralanabilir. Bu araştırma sonuçları cinsiyetin iyilik halini yordayabileceğini akla getirmektedir.

Diğer taraftan bir toplumda gençlerin geleceğe yönelik beklentileri o toplumun çizgisini ve dinamiğini belirleyen en önemli etkenlerden biridir (Güleri 1999, 56). Literatürde gelecek 
zaman tutumu (future time attitude), gelecek zaman yönelimi (future time orientation) ve gelecek zaman perspektifi (future time perspective) olmak üzere üç kavram kullanılmakta ve bu kavramlar arasında farklılıklar bulunmaktadır. Gelecek zaman perspektifi, bireylerin geleceğe yönelik kapsamlı, yapılanma derecesi olan ve ne derece gerçekçi planlar yaptıklarıyla ilgilidir. Gelecek zaman yönelimi ise bireylerin düşünce ve davranışlarında geçmiş, şimdi, gelecek olmak üzere tercih ettikleri zaman yönelimini ifade etmektedir (van Calster, Lens \& Nuttin 1987, 1-2). Seginer $(2003$, 2) gelecek yönelimini, bireylerin kendi geleceklerine ilişkin sahip oldukları imaj olarak tanımlamaktadır. Nurmi $(1991,2)$ ise gelecek yönelimini karmaşık ve çok boyutlu bir süreç olarak tanımlamış ve gelecek yönelimini motivasyon, planlama ve değerlendirme olmak üzere üç temel psikolojik süreçle açıklamıştır. Buna göre, bireyler ilk olarak güdüleri, değerleri ve geleceğe yönelik beklentileri arasında karşılaştırmaya dayanan hedefler koymakta, daha sonra bu hedefleri nasıl gerçekleştirebilecekleri üzerinde çalışmakta ve bu genellikle planlama ve problem çözme yoluyla yapılmaktadır. Son olarak bireyler, hedeflerine ulaşma olasılığını değerlendirmekte ve oluşturdukları planı gerçekleştirmektedirler. Zamana yönelik tutum ise bireylerin geçmiş, bugün ya da geleceklerine yönelik geliştirdikleri pozitif veya negatif duygusal yönelimleridir. Bireyler geçmişleri ve şimdiki zamanları konusunda negatif bir tutuma sahip olabilirken gelecekleri konusunda genellikle pozitif ve iyimser bir tutuma sahip olmaktadırlar (Nuttin 1985, 91). Gelecek beklentisine ilişkin kavramsallaştırmalar bu alanda araştırmalar yürüten Frank (1939) gibi psikologların erken dönem çalışmalarına dayanmaktadır. $\mathrm{Bu}$ araştırmacıların analizleri ilegelecek yöneliminin kavramsallaştırılmasına ve aynı zamanda gelecek yöneliminin güdüsel ve gelişimsel fonksiyonlarına vurgu yapılmış ve özellikle üç konu üzerinde durulmuş̧tur (Seginer 2003, 3-4):

a) Gelecek yönelimi veya gelecekteki olası olaylar ve deneyimler, mevcut zamanda oluşturulur.

b) Gelecek yönelimi alana özgüdür ve bireyler farklı alanlara ilişkin gelecek imajlarını oluştururlar.

c) $\mathrm{Bu}$ alanların içeriği kişisel ya da toplumsal, gerçekçi ya da ideal ve gerçeğe dayalı ya da fantastik olabilir.

Gençlerin geleceğe yönelik beklentileri ve bu beklentilerin gerçekleşmesine ilişkin umutları hem onların ruh sağlığı ve yaşamlarından hoşnut olma düzeylerini etkileyebilmekte hem de toplumun değişimini ve bu değişimin yönünü belirlemede etkili olabilmektedir (Yavuzer et al. $2005,94)$. Gençlerin gelecekle ilgili beklentileri farklılık gösterse de yapılan kültürlerarası çalışmalarda bu beklentilerin kariyer, aile ve romantik ilişkiler olmak üzere üç konu üzerinde yoğunlaştığı görülmektedir (Yavuzer et al. 2005, 94). Bir başka araştırmada ise gençlerin romantik ilişkiler ve aile ilişkileriyle kıyaslandığında gelecekteki kariyerlerine yönelik daha iyimser ve gerçekçi oldukları belirlenmiştir (McCabe et al. 2000). Zaman konusu üzerinde çok eskiden beri durulmasına rağmen "Gelecek zamana ilişkin ne tür yönelimler olabilir ve söz konusu yönelimlerde ne gibi bireysel farklllıklar gözlenebilir?" gibi sorulara yakın zamana kadar gereken önen verilmemiş fakat son yıllarda zaman yöneliminin psikolojik çıktıları üzerinde durulmaya başlanmıştır (İmamoğlu \& Güler-Edwards 2007, 116).

Ulusal ve uluslararası literatürde olumlu gelecek beklentisiyle ilgili birtakım çalışmalar olduğu görülmektedir. Eryılmaz (2011) yaptıkları araştırmada ergenlerin öznel iyilik halleri ve olumlu gelecek beklentileri arasında olumlu bir ilişki belirlemiş ve lise öğrenimi gören ergenlerin öznel iyilik hali düzeyinin yükseltilmesinde olumlu gelecek beklentisine sahip olmalarının önemini işaret etmişlerdir. İmamoğlu ve Güler-Edwards (2007) öğrencilerin geleceğe ilişkin yönelimlerini benlik tipine bağlı farklılıklar açısından ele almışlar ve araştırma sonucunda kız 
öğrencilerin erkeklere kıyasla geleceğe daha kaygılı yaklaştıkları sonucuna varmışlardır. Şanlı ve Saraçlı (2015) üniversite öğrencilerinin gelecek beklentileri üzerinde etkili olan etmenleri belirlemek üzere bir araştırma yürütmüş ve öğrencilerin gelecek beklentileri üzerinde kişilik özelliklerinin en büyük etkiye sahip olduğunu belirlemişlerdir. Üniversite öğrencilerinin gelecekle ilgili beklentilerinin araştırıldığı bir başka araştırmada (Güleri 1999) gençlerin gelecek beklentisi üzerinde gençlerin aile olanakları, eğitim-öğretim firsatları ve yetenek ve beceri düzeylerinin önemli rol oynadığı belirlenmiştir. Uluslararası yazında ise gelecek yönelimi ile ergenlerin beklentileri (Greene 1986; Nurmi 1991; Seginer 2003), kayg1 ve depresyon (MacLeod \& Byrne 1996), dayanıklılık ve sosyal öz-yeterlilik (Smorti 2015), akademik başarı (Devolder \& Lens 1982), planlama, motivasyon ve değerlendirme (Nurmi 1989), iyilik hali (Shobe \& Page-Adams 2001; Johnson, Blum \& Cheng 2014) gibi değişkenler arasındaki ilişkiler incelenmiştir. Alanyazın incelendiğinde psikolojik iyilik hali ve geleceğe yönelik tutum ve olumlu gelecek beklentisi arasındaki ilişki turizm alanında oldukça sınırlı sayıdaki araştırmaya dayanmaktadır.

Mevcut araştırmanın bir yönüyle üniversite öğrencilerinin geleceğe ilişkin yönelimler ve psikolojik iyilik hali arasındaki ilişkiyi ortaya koyması bakımından, diğer yönüyle de bu doğrultuda yapılabilecek koruyucu/önleyici ve geliştirici programların hazırlanmasında yararlanılabilecek bir bilgi kaynağı olması bakımından literatüre katkı sağlayacağı düşünülmektedir.

\section{Yöntem}

Araştırmanın evrenini, Akdeniz Üniversitesi Turizm Fakültesinde öğrenim gören öğrenciler oluşturmaktadır. Araştırmanın örneklemini ise Akdeniz Üniversitesi Turizm Fakültesinde konaklama, seyahat, turizm işletmeciliği İngilizce, gastronomi ve mutfak sanatları ve rehberlik bölümünde öğrenim gören öğrenciler oluşturmaktadır. Anket çalışması 2015 yılı Mart ayında başlamış ve Aralık ayında son bulmuştur. Kolayda örnekleme yöntemi ile seçilen 807 öğrenci üzerinde araştırma yürütülmüştür.

Araştırmanın örnekleminin \%47,5'ini (383) kı öğrenciler, \%52,5'ini (424) erkek öğrenciler oluşturmaktadır. Öğrencilerin öğrenim gördükleri bölümler incelendiğinde ise büyük bir çoğunluğunun (283) konaklama işletmeciliği bölümünde eğitim aldıkları görülmektedir. Araştırmaya katılan öğrencilerin büyük bir kısmı \%43,4 (350) 3. Sınıf öğrencilerinden oluşmaktadır. Öğrencilerin aylık aile gelir durumuna bakıldığında en yüksek grubu \%42,2 oranı ile "2001 ve üzeri aylık gelir" düzeyine sahip katılımcılar oluşturmaktadır. Bunun yanında elde edilen veriler doğrultusunda, öğrencilerin büyük bir çoğunluğunun \%51,9 (419) büyükşehirde yaşadığı görülmektedir.

\section{Veri Toplama Araçları}

Katılımcılara aşağıda ayrıntıları verilen daha önceki çalışmalarda geçerliliği ve güvenilirliği kanıtlanmış iki ölçek uygulanmıştır. Araştırmada kullanılan anket üç ayrı bölümden oluşmaktadir. Anketin ilk bölümünde öğrencilerin demografik özelliklerine yönelik sorular yer almakta, ikinci bölümde katılımcıların geleceğe yönelik tutum ve olumlu gelecek beklentisine ilişkin sorular bulunmakta ve üçüncü bölümde ise katılımcıların psikolojik iyilik hallerini ölçmeye yönelik sorular yer almaktadır.

\section{Psikolojik İyilik Hali Ölçeği}

Öğrencilerin psikolojik iyilik hallerini ölçmek amacıyla Diener ve diğerleri (2010) tarafından geliştirilen ve Fidan ve Usta (2013) tarafından Türkçeye çevrilen İyilik Hali Ölçeği (İHÖ) kullanılmıştır. Türkçeye uyarlaması yapılan psikolojik iyilik hali ölçeği 8 maddeden oluşmaktadır. Kesinlikle katılıyorum (5)'dan Kesinlikle katılmıyorum (1)'a doğru sıralanan 5'li Likert tipi bir ölçektir. İyilik hali ölçeğinin Alfa iç tutarlılık katsayısı 0.862 çıkmıştır. 


\section{Olumlu Gelecek Beklentisi ve Tutum Ölçeği}

Bireylerin kişisel gelecekleri hakkındaki beklenti ve tutumlarını ölçmeyi amaçlayan bu ölçek İmamoğlu (2001) tarafından geliştirilmiştir. Olumlu gelecek beklentisi ölçeği beş maddeden, geleceğe yönelik tutum ölçeği ise on beş maddeden oluşmaktadır. Toplam yirmi maddeden oluşan bu ölçek Kesinlikle katılıyorum (5)'dan Kesinlikle katılmıyorum (1)'a doğru sıralanan 5'li Likert tipi bir ölçektir. Ölçeğin alfa güvenilirlik katsayısı önceki çalışmalarda 0,85 (İmamoğlu 2001) ve 0,92 (İmamoğlu 2005) olarak belirtilmiştir. Bu çalışmada ise olumlu gelecek beklentisi ölçeğinin güvenilirlik katsayısı .735 ve geleceğe yönelik tutum ölçeğinin güvenilirlik katsayısı ise .745 olarak bulunmuştur.

\section{Verilerin Analizi}

Çalı̧̧ma verilerinin analizinde SPSS18 paket programından yararlanılmıştır. Verilerin analizinde öncelikle varyansların homojenliği test edilmiş ve daha sonra ise verilerin normal dağılıma sahip olup olmadığı incelenmiştir. Yapılan analizler sonucunda veriler normal dağılım gösterdiği ve varyanslar homojen olduğu için parametrik testlerin uygulanabilirliğine karar verilmiştir. Daha sonra araştırmanın amacına uygun olarak Bağımsız Gruplar için T-Testi, Tek Yönlü Varyans Analizi (Anova), Pearson Korelasyon Analizi ve Basit Doğrusal Regresyon Analizi uygulanmıştır. Bunun yanında çalışmada bağımlı ve bağımsız değişkenlere ilişkin ortalama, standart sapma gibi betimsel istatistik analizlerine de yer verilmiştir. İstatistiksel anlamlılık düzeyi en az $\mathrm{p}<0.05$ olarak kabul edilmiştir.

\section{Bulgular}

$\mathrm{Bu}$ bölümde öğrencilerin psikolojik iyilik hallerinin geleceğe yönelik tutum ve olumlu gelecek beklentilerine etkisini belirlemek üzere öncelikle ele alınan değişkenlerin betimsel istatistiklerine yer verilmiş daha sonra bağımlı ve bağımsız değişkenler arasındaki ilişkileri incelemek için ise Basit Doğrusal Regresyon ve Pearson Korelasyon analizleri gerçekleştirilmiş ve sonuçlarına yer verilmiştir.

\section{Pearson Korelasyon Analizi}

Araştırmaya katılan öğrencilerin geleceğe yönelik tutum ve olumlu gelecek beklenti düzeyleri ile psikolojik iyilik hali arasındaki ilişkinin belirlenmesi amacıyla pearson korelasyon analizi uygulanmıştır. Analiz sonuçları Tablo 1'de gösterilmiştir.

\begin{tabular}{|c|c|c|c|c|}
\hline Değişkenler & & (1) & (2) & (3) \\
\hline \multirow{3}{*}{ (1) Psikolojik İyilik Hali } & $\mathrm{r}$ & 1 & & \\
\hline & $\mathrm{p}$ & . & & \\
\hline & $\mathrm{N}$ & 801 & & \\
\hline \multirow{3}{*}{ (2) Olumlu Gelecek Beklentisi } & $\mathrm{r}$ & $0,688^{* *}$ & 1 & \\
\hline & $\mathrm{p}$ & 0,000 & . & \\
\hline & $\mathrm{N}$ & 798 & 806 & \\
\hline \multirow{3}{*}{ (3) Geleceğe Yönelik Tutum } & $\mathrm{r}$ & $0,566^{* *}$ & $0,667^{* *}$ & 1 \\
\hline & $\mathrm{p}$ & 0,000 & 0,000 & . \\
\hline & $\mathrm{N}$ & 793 & 797 & 800 \\
\hline Ortalama & & 3.98 & 3.78 & 3.66 \\
\hline SS & & 0.604 & 0.676 & 0.530 \\
\hline
\end{tabular}

*p<.05, **p<.01 r: Pearson korelasyon katsayıs1 p: anlamlılık N: öğrenci sayısı 
Öğrencilerin geleceğe yönelik tutum ve olumlu gelecek beklenti düzeyleri ile psikolojik iyilik hali arasında anlamlı bir ilişki olup olmadığı Pearson Korelasyon Katsayısı ile incelenmiştir. Korelasyon analizinde ortaya çıkan bulgular, Pearson korelasyon katsayısının 0,30'un altında olmas1 durumunda "düşük", 0,30-0,69 arasında orta ve 0,70 ve daha büyük değerler için “yüksek" şeklinde (Çokluk vd. 2012, 52) nitelendirilmiştir. Tablo 1'de görüldüğü üzere, öğrencilerin geleceğe yönelik tutum ve olumlu gelecek beklentileri ile psikolojik iyilik hali arasında istatistiki olarak anlamlı bir ilişki bulunmuştur $(\mathrm{p}<0,01)$. Değişkenler arasında doğru yönlü (pozitif) orta kuvvetli bir ilişki (korelasyon) vardır. Geleceğe yönelik tutum ile psikolojik iyilik hali arasında anlamlı ve pozitif bir ilişki bulunmaktadır $(\mathrm{r}=0,566)$. Bu sonuca göre, geleceğe yönelik tutum arttıkça psikolojik iyilik halinin de arttığı görülmüştür. Öğrencilerin olumlu gelecek beklentileri ve psikolojik iyilik hali arasında doğru yönlü ve orta kuvvetli bir ilişki vardır $(\mathrm{r}=0,688)$. Bu doğrultuda, olumlu gelecek beklentisi arttıkça psikolojik iyilik hali de artmaktadır. Son olarak, geleceğe yönelik tutum ve olumlu gelecek beklentisi arasında pozitif yönlü ve orta kuvvetli bir ilişki vardır (r=0,667).

\section{Basit Doğrusal Regresyon Analizi}

Çalışmada öğrencilerin geleceğe yönelik tutum ve olumlu gelecek beklentisinin psikolojik iyilik halinin üzerindeki etkisini belirlemek üzere yapılan basit doğrusal regresyon analiz sonuçları Tablo 2 ve Tablo 3'te gösterilmiştir.

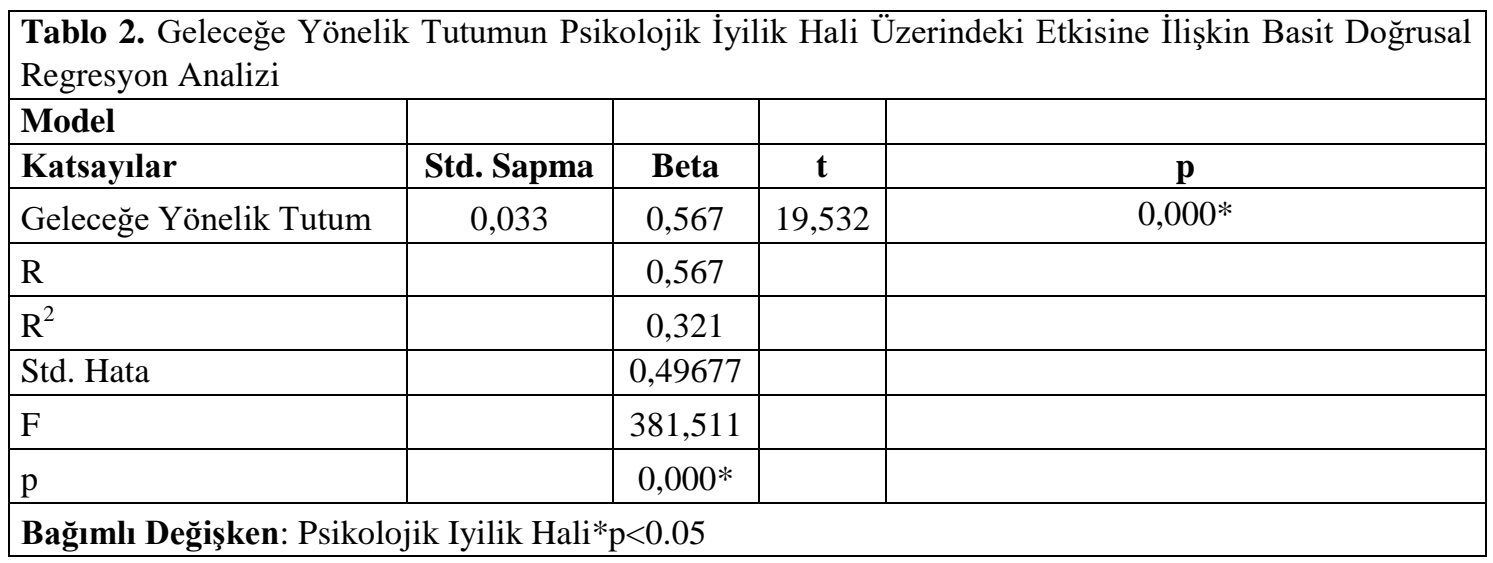

Tablo 2'de görüldüğg̈ gibi, geleceğe yönelik tutumun psikolojik iyilik hali üzerindeki etkisine ilişkin gerçekleştirilen basit doğrusal regresyon modelinin anlamlı olduğu tespit edilmiştir ( $\mathrm{F}=381,511$; $\mathrm{p}<0,001)$. Tablo 2'deki belirtme katsayısı $\left(\mathrm{R}^{2}=0,321\right)$ ögrencilerin psikolojik iyilik hali üzerindeki değişimlerin \%32,1'inin geleceğe yönelik tutum algılarından kaynaklandığını göstermektedir. Psikolojik iyilik hali ile geleceğe yönelik tutum arasındaki korelasyon katsayıları incelendiğinde, pozitif yönde ve orta kuvvette $(0,30<\mathrm{r}<0,69)$ bir ilişki olduğu görülmektedir $(\mathrm{r}=0,567)$.

Tablo 3. Olumlu Gelecek Beklentisinin Psikolojik İyilik Hali Üzerindeki Etkisine İlişkin Basit Doğrusal Regresyon Analizi

\begin{tabular}{|l|c|c|c|c|}
\hline Model & & & \\
\hline Katsayılar & Std. Sapma & Beta & t & p \\
\hline Olumlu Gelecek Beklentisi & 0,023 & 0,683 & 26,590 & $0,000^{*}$ \\
\hline $\mathrm{R}$ & & 0,683 & & \\
\hline $\mathrm{R}^{2}$ & & 0,467 & & \\
\hline Std. Hata & & 0,44014 & & \\
\hline $\mathrm{F}$ & & 707,024 & & \\
\hline $\mathrm{p}$ & & $0,000^{*}$ & & \\
\hline Bağımlı Değişken: Psikolojik İyilik Hali*p<0.05 & & \\
\hline
\end{tabular}


Tablo 3'te görüldüğü gibi, olumlu gelecek beklentisinin psikolojik iyilik hali üzerindeki etkisine ilişkin gerçekleştirilen basit doğrusal regresyon modelinin anlamlı olduğu tespit edilmiştir $(F=707,024 ; p<0,001)$. Tablo 3'teki belirtme katsayıs1 $\left(R^{2}=0,467\right)$, öğrencilerin psikolojik iyilik hali üzerindeki değişimlerin \%46,7'ünün olumlu gelecek beklentisi algılarından kaynaklandığını göstermektedir. Üniversite öğrencilerinin olumlu gelecek beklentisi ile psikolojik iyilik hali arasındaki korelasyon katsayıları incelendiğinde, pozitif yönde ve orta kuvvette $(0,30<\mathrm{r}<0,69)$ bir ilişki olduğu görülmektedir $(\mathrm{r}=0,683)$. Elde edilen verilere göre olumlu gelecek beklentisinin $(0,467)$, geleceğe yönelik tutuma $(0,321)$ oranla psikolojik iyilik halini daha çok etkilediği söylenebilir.

\section{Sonuç ve Öneriler}

Araştırmanın amacı, turizm öğrencilerin geleceğe yönelik tutum ve olumlu gelecek beklentilerinin psikolojik iyilik hali durumunun ne oranda etkilendiğini ortaya çıkarabilmektir. Araştırma sonuçları öğrencilerin geleceğe yönelik tutum ve olumlu gelecek beklentileri ile psikolojik iyilik hali arasında pozitif yönde anlamlı bir ilişki olduğunu, olumlu gelecek beklentisinin, geleceğe yönelik tutuma oranla psikolojik iyilik halini daha çok etkilediğini göstermektedir.

Araştırmanın ortaya koyduğu bir diğer önemli sonuç da öğrencilerin psikolojik iyilik hali üzerindeki değişimlerin \%46,7'sinin olumlu gelecek beklentisi algılarından kaynaklandığ yönündedir. Şimşek (2012)'in de üzerinde önemle durduğu üzere gelecek beklentisi, bireylerin gelecekle bağlantılı ilgi, görüş ve kaygılarını barındıran bilişsel haritalardır. Benzer şekilde Doğan (2006) da üniversite öğrencileri üzerine gerçekleştirdiği araştırmasında öğrencilerin gelecekle ilgili düşünceleri olumlu oldukça "İyilik hali" düzeylerinin de yükseldiğini göstermekedir. İlgili yazın incelendiğinde üniversite öğrencilerinin geleceğe bakış açısı ile psikolojik iyilik hali arasındaki ilişkiyi inceleyen sınırlı sayıda araştırma bulunmaktadır. Weiss ve Cropanzano (1996) tarafından da vurgulandığı gibi olumlu duygulanım stresi, depresyonu, umutsuzluğu azaltma, iyilik halini artırıcı yönde olumlu katkı sağlamaktadır. Şu halde bu çalışmanın ortaya koymuş olduğu sonuçların sözü edilen çalışmalarla benzer nitelikte olduğu söylenebilir. Buradan hareketle öğrencilerin gelecekle ilgili düşünceleri olumluya doğru gittikçe psikolojik iyilik halinin de yükseleceği söylenebilir.

Gelecek, daha gerçekleşmemiş ama bireylerin arzuları doğrultusunda yaşamayı istediği, hayatın insanları hep ileriye yönelten bir bölümüdür. Yaşam amacı insanın önündeki hedef veya yol gösteren bir 1şık gibidir. Toplumda gençlerin geleceğe ilişkin beklentileri ise toplumun gelişim çizgisini ve dinamiğini belirleyen önemli etkenlerdendir. Çünkü gençlik, toplum için potansiyel bir güçtür. $\mathrm{Bu}$ açıdan fakültelerin kuramsal prensiplerinde fakülte öğrencilerinin geleceğe ilişkin beklenti ve tutumlarını ve psikolojik iyilik hallerinin anlaşılmasına yönelik stratejiler geliştirmesi gerektiği söylenebilir. Bu şekilde öğrenciler ile kurulacak yakın iletişim ve ortak misyon açısı ile bu konuda iyileştirici önlemler sağlanabilir. Fakültelerde psikolojik danışmanlık ve rehberlik platformları oluşturulabilir. Bunun yanı sıra fakülteler öğrenci odaklı araştırmalar yaparak fakültelerin daha önce gözardı ettiği bazı hizmet sunumlarını gerçekleştirebilir ve gelecek beklentisinde rol oynayan güvenilen dayanakları tespit ederek iyileştirici önlemler alabilirler. Bu tür araştırmalar sayesinde öğrenci memnuniyetini arttıran farklı ve yenilikçi uygulamalar hayata geçirilerek diğer fakülteler karşısında rekâbet avantajı elde edilebilir. Bunları önlemek amacıyla gençlerin kişilikleri kabul edilmeli, özellikle üniversitede öğrencilere rehberlik ve psikolojik yardım verilmesi konusunda çalışmalar yoğunlaştırılmalı ve her gencin rahatlıkla bu hizmetten yararlanabileceği düzeye getirilmelidir. Gençlik insan hayatının kuşkusuz en önemli ve etkin bir dönemini ifade etmektedir. Bu açıdan bakıldığında bir olgu olarak gençlik ve onun sorunları da önemli konulardır. Çalışmanın bu yönüyle ülkemizin geleceği olan 
gençleri anlamada, sorunları çözmede, imkânlarını geliştirmede ve onlara sahip çıkmada yol gösterici olacă̆ına inanılmaktadır.

$\mathrm{Bu}$ çalışmanın diğer çalışmalarda da olduğu gibi birtakım kısıtları bulunmaktadır. Bu çalışmanın kısıtı, verilerin yalnız üniversite öğrencilerinden toplanmış olmasıdır. Ancak, farklı biçimlerde olsa da, zamanın her yaş grubu için önemli olduğu dikkate alınarak, sektöre yönelik gelecekte yapılacak araştırmalarda farklı yaş gruplarının zaman yönelimlerinde gözlenen farklılıkların irdelenmesi önerilebilir. Ayrıca mevcut bulguların farklı turizm fakültelerinde ne derece geçerli olduğunun da gelecekte yapılacak çalışmalarda sınanması uygun olacaktır. Son olarak ileride yapılacak çalışmalarda turizm sektörünün farklı alanlarında (konaklama işletmeleri, seyahat acenteleri, yiyecek-içecek işletmeleri vb.) söz konusu olan çalışanların geleceğe ilişkin yönelimleri ve psikolojik iyilik hallerinin davranışsal niyet, sadakat, bağl1lik, sektörde kalma, işten ayrilma niyeti vb. gibi değişkenlerle ilişkisinin incelenmesi tavsiye edilebilir. Bununla birlikte çalışmalar farklı nitel ve nicel araştırma yöntemleri ile desteklenerek karşılaştırmalar yapılarak ilgili alan yazına katkı sağlanabilir. 


\section{KAYNAKÇA}

Aksu A. A. \& Köksal C. D. (2005). "Perceptions and attitudes of tourism students in Turkey". International Journal of Contemporary Hospitality Management 17/5 (2005) 436-447.

Altman L. A. \& Brothers L. R. (1995). “Career longevity of hospitality graduates". FIU Hospitality Review 13/2 (1995) 77-83.

Baron P. \& Maxwell G. (1993). "Hospitality Management Students' Image of the Hospitality Industry". International Journay of Contemporary Hospitality Management $5 / 5$ (1993) 5-8.

Betton A. C. (2001). Psychological Well Being: A Comparison of Correlates Aamong Minority and NonMinority Female College Students. Doctoral Dissertation. Ohio State University, USA 2001.

Bradburn N. M. (1969). The Structure of Psychological Well-Being. Chicago 1969.

Braun P. M. W. (1976). Psychological Well-being and Location in the Social Structure. Doctoral Dissertation. University of South California, Los Angeles, California 1976.

Cenkseven F. \& Akbaş T. (2004). "Üniversite Öğrencilerinde Öznel ve Psikolojik İyi Olmanın Yordayıcılarının İncelenmesi”. Türk Psikolojik Danışma Ve Rehberlik Dergisi 27/3 (2004) 43-65.

Çeçen R. \& Cenkseven F. (2007). "Üniversite Öğrencilerinde Yalnızlığın Yordayıcısı Olarak Psikolojik İyi Olma”. Çukurova Üniversitesi, Sosyal Bilimler Enstitüsü Dergisi 16/2 (2007) 109-118.

Çokluk Ö., Şekercioğlu G. \& Büyüköztürk Ş. (2012). Sosyal Bilimler İçin Çok Değişkenli İstatistik SPSS ve Lisrel Uygulamalart. Ankara 2012.

Deci E. L. \& Ryan R. M. (2008). “Hedonia, Eudaimonia, and Well-Being: An Introduction”. Journal of Happiness Studies 9/1 (2008) 1-11.

Devolder M. L. \& Lens W. (1982). “Academic Achievement and Future Time Perspective: A CognitiveMotivational Concept". Journal of Personality and Social Psychology 42 (1982) 571-655.

Diener E. (2000). "Subjective Well-Being: The Science of Happiness and a Proposal for a National Index". American Psychologist 55/1(2000) 34-43.

Diener E., Wirtz D., Tov W., Kim-Prieto C., Choi D. W., Oishi S. \& Biswas-Diener R. (2010). "New well-Being Measures: Short Scales to Assess Flourishing and Positive and Negative Feelings". Social Indicators Research 97/2 (2010) 143-156.

Doğan, T. (2006). “Üniversite Öğrencilerinin Iyilik Halinin Incelenmesi”. Hacettepe Üniversitesi Ĕgitim Fakültesi Dergisi 30 (2006) 120-129.

Dunn H. L. (1959). "What High-Level Wellness Means". Canadian Journal of Public Health/ Revue Canadienne De Sante'e Publique 50/11 (1959)447-457.

Eryılmaz A. (2011). "Ergen Öznel İyi Oluşu ile Olumlu Gelecek Beklentisi Arasındaki İlişkinin İncelenmesi”. Düşünen Adam Psikiyatri ve Nörolojik Bilimler Dergisi 24 (2011) 209-215.

Fidan M. ve Usta F. (2013). "İyilik Hali Ölçeğinin Türkçe Formunun Güvenirlik ve Geçerliğinin İncelenmesi”. Eğitim ve Öğretim Araştırmaları Dergisi 2/3 (2013) 265-269.

Filep S. (2016). “Tourism and Positive Psychology Critique: Too Emotional?". Annals of Tourism Research 59 (2016) 113-115.

Francis L. J. \& Kaldor P. (2002). "The Relationship between Psychological Well-Being and Christian Faith and Practice in an Australian Population Sample". Journal for the Scientific Study of Religion 41/1 (2002) 179-184.

Frank L. K. (1939). "Projective Methods for the Study of Personality". The Journal of Psychology 8/2 (1939) 389-413.

Getz D. (1994). "Students' Work Experinces, Perceptions and Attitudes Towards Careers in Hospitality and tourism: A Longitudinal Case Study in Spey Valley, Scotland". International Journal of Hospitality Management 13/1 (1994) 25-37.

Granello P. F. (1999). “College Students' Wellness as a Function of Social Support and Empathic Ability". Journal of College Counseling 2/2 (1999) 110-120.

Greene A. L. (1986). "Future-Time Perspective in Adolescence: The Present of Things Future Revisited". Journal of Youth and Adolescence 15/2 (1986) 99-113. 
Güleri M. (1999). “Üniversiteli ve İşçi Gençliğin Gelecek Beklentileri Ve Kötümserlik-İyimserlik Düzeyleri”. Kriz Dergisi 6/1 (1999) 55-65.

Gürel N. A. (2009). Effects of Thinking Styles and Gender on Psychological Well-Being. Yayınlanmamış Yüksek Lisans Tezi. Orta Doğu Teknik Üniversitesi, Ankara 2009.

İmamoğlu, S. (2005). Secure Exploration: Conceptualization, Type, and Relationships with Secure Attachment, Selfconstruals and Other Self-Related Variables. Yayınlanmamış Doktora Tezi. Orta Doğu Teknik Üniversitesi, Ankara 2005.

İmamoğlu E. O. \& Güler-Edwards A. (2007). "Geleceğe İlişkin Yönelimlerde Benlik Tipine Bağlı Farklılıklar". Türk Psikoloji Dergisi 22/60 (2007) 115-132.

İmamoğlu E. O. (2001). Need for Cognition Versus Recognition: Self and Family Related Correlates. Yayımlanmamış Makale. Orta Doğu Teknik Üniversitesi, Ankara.

Johnson S. R. L., Blum R.W. \& Cheng T. L. (2014). "Future Orientation: A Construct with Implications for Adolescent Health and Wellbeing". International Journal of Adolescent Medicine and Health 26/4 (2014) 459-468.

Kagan S. (1992). "The Limits of Well-Being". Eds. E. F. Paul, F. D. Miller Jr. \& J. Paul, The Good Life and the Human Good (1992) 169-189. Cambridge.

Kararrmak Ö. \& Siviş R. (2008). "Modernimden Postmodernizme Geçiş ve Pozitif Psikoloji". Türk Psikolojik Danlşma ve Rehberlik Dergisi 30 (2008)102-115.

Kasapoğlu F. (2014). "İyilik Hali ile Özgecilik Arasındaki İlişsinin İncelenmesi”. Hikmet Yurdu: Düşünce-Yorum Sosyal Bilimler Araştırma Dergisi $7 / 7$ (2014) 271-288.

Keyes C. L., Shmotkin D. \& Ryff C. D. (2002). "Optimizing Well-Being: The Empirical Encounter of two Traditions". Journal of Personality and Social Psychology 82/6 (2002) 1007.

Khumalo I. P., Temane Q. M. \& Wissing M. P. (2012). "Socio-Demographic Variables, General Psychological Well-Being and the Mental Health Continuum in an African Context". Social Indicators Research 105/3 (2012) 419-442.

Kızılırmak İ. (2000). "Meslek Yüksekokulları Turizm ve Otelcilik Programlarının Günümüz Turizm Sektörünün Beklentileri Doğrultusunda Değerlendirilmesi”. Kaynak: http://dhgm.meb.gov.tr/yayimlar/ dergiler/milli_egitim_dergisi/147/kizilirmak.htm

Kim H. K. \& McKenry P. C. (2002). "The Relationship between Marriage and Psychological Well-Being: A Longitudinal Analysis". Journal of Family Issues 23/8 (2002) 885-911.

Kozak M. \& Kızılırmak İ. (2001). “Türkiye'de Meslek Yüsekokulu Turizm Otelcilik Programı Öğrencilerinin Turizm Sektörüne Yönelik Tutumlarının Demografik Değişkenlere Göre Değişimi: Anadolu, Akdeniz ve Karadeniz Teknik Üniversitesi Öğrencileri Üzerine Bir Uygulama”. Anatolia Turizm Araştrmaları Dergisi 12/Bahar (2001) 9-16.

Kuşluvan S. \& Kuşluvan Z. (2000). "Perceptions and Attitudes of Undergraduate Tourism Students towards Working in the Tourism Industry in Turkey". Tourism Management 21 (2000) 251-269.

Kuyumcu B. \& Güven M. (2012). "Türk ve İngiliz Üniversite Öğrencilerinin Duygularını Fark Etmeleri ve İfade Etmeleri ile Psikolojik İyi Oluşları Arasındaki İlişki”. Gazi Üniversitesi Eğitim Fakültesi Dergisi (GEFAD) 32/3 (2012) 589-607.

Lawton M. P. (1983). "Environment and Other Determinants of Well-Being in Older People". The Gerontologist 23/4 (1983) 349-357.

Macleod A. K. \& Byrne A. (1996). "Anxiety, Depression and the Anticipation of Future Positive and Negative Experiences". Journal of Abnormal Psychology 105/2 (1996) 286-289.

Mccabe C., Kristen D., Barnett A. \&Douglas, S. (2000). "First Comes Work, then Comes Marriage: Future Orientation among African American Young Adolescents". Family Relations 49/1 (2000) 63-70.

Myers J. E., Sweeney T. J. \& Witmer J. M. (2000). "The Wheel of Wellness Counseling for Wellness: A Holistic Model for Treatment Planning”. Journal of Counseling and Development 78 (3) 251-266.

Nurmi J. E. (1989). "Planning, Motivation and Evaluation in Orientation to the Future: A Latent Structure Analysis". Scandinavian Journal of Psychology 30/1 (1989) 64-71.

Nurmi J. E. (1991). "How Do Adolescents See Their Future? A Review of the Development of Future 
Orientation and Planning”. Developmental Review 11/1 (1991) 1-59.

Nuttin J. \& Lens W. (1985). Future Time Perspective and Motivation: Theory and Research Method. Leuven 1985.

Pavesic D. V. \& Brymer R.A. (1990). “Job Satisfaction: What's Happening to the Young Managers?”. The Cornell Hotel and Restaurant Administration Quarterly 30/4 (1990) 90-96.

Perez J. A. (2012). "Gender Difference in Psychological Well-Being among Filipino College Students Samples”. International Journal of Humanities and Social Science 13/2 (2012) 84-93.

Ryan R. M. \& Deci E. L. (2001). "On Happiness and Human Potentials: A Review of Research on Hedonic and Eudaimonic Well-Being”. Annual Review of Psychology 52 (2001) 141-166.

Ryan R. M., Huta V. \& Deci E. L. (2008). "Living Well: A Self-Determination Theory Perspective on Eudaimonia". Journal of Happiness Studies 9 (2008) 139-170.

Ryff C. D. (1995). "Psychological Well-being in Adult Life". Current Directions in Psychological Science. 4/4 (1995) 99-104.

Ryff C. D., Magee W. J., Kling K. C. \& Wing E. H. (1999). "Forging Macro-Micro Linkages in the Study of Psychological Well-Being”. Eds. C. D Ryff \& V. W Marshall, In the Self and Society in Aging Processes (1999) 247-78. New York.

Sarıcaoğlu H. \& Arslan Ç. (2013). "Üniversite Öğrencilerinin Psikolojik İyi Olma Düzeylerinin kişilik Özellikleri ve Öz-Anlayış Açısından İncelenmesi”. Kuram ve Uygulamada Ĕgitim Bilimleri 13/4 (2013) 2087-2104.

Scully D., Kremer J., Meade M. M., Graham R. \& Dudgeon K. (1998). "Physical Exercise and Psychological Well-Being: A Critical Review”. British Journal of Sports Medicine 32/2 (1998) 111-120.

Seginer R. (2003). "Adolescent Future Orientation: An Integrated Cultural and Ecological Perspective". Online Readings in Psychology and Culture 6/1 (2003) 3-13.

Shobe M. \& Page-Adams D. (2001). "Assets, Future Orientation, and Well-Being: Exploring and Extending Sherraden's Framework”. Journal Of Sociology And Social Welfare 28/3 (2001) 109-127.

Smorti M. (2015).“Expectations towards Future, Resiliency, Social Self-Efficacy in Adolescents after Bone Cancer Treatment". Procedia-Social and Behavioral Sciences 185 (2015) 123-127.

Srimathi N. L. \& Kiran S. K. (2010). "Psychological Well Being of Employed Women Across Different Organisations". Journal of the Indian Academy of Applied Psychology 36/1 (2010) 89-95.

Şanlı T. \& Saraçlı S. (2015). "Üniversite Öğrencilerinin Gelecek Beklentileri Üzerinde Etkili Olan Faktörlerin Analizi”. Kafkas Üniversitesi İktisadi ve İdari Bilimler Fakültesi Dergisi 6/11 (2015) 25-36.

Şeker B. D. \& Akman E. (2015). "Farklı Ülkelerden Üniversite Öğrencilerinin Psikolojik İyi Olma ve Yaşam Doyumları Üzerine Bir Araştırma”. Celal Bayar Üniversitesi Sosyal Bilimler Dergisi 13/1 (2015) 106-119.

Şimşek H. (2012). "Güneydoğu Anadolu Bölgesindeki Lise Öğrencilerinin Gelecek Beklentileri ve Gelecek Beklentilerini Etkileyen Faktörler.” Kuramsal Eğitimbilim Dergisi 5/1 (2012) 90-109.

van Calster K., Lens W. \& Nuttin J. R. (1987). “Affective Attitude toward the Personal Future: Impact on Motivation in High School Boys”. American Journal of Psychology 100/1 (1987) 1-13.

Weiss, H. M., \& Cropanzano, R. (1996). "Affective Events Theory: A Theoretical Discussion of the Structure, Causes and Consequences of Affective Experiences at Work". Research in Organizational Behavior 18 (1996) 1-74

Yavuzer H., Demir İ., Meşeci F. \& Sertelin Ç. (2005). “Günümüz Gençliğinin Gelecek Beklentileri”. Hasan Ali Yücel Eğitim Fakültesi Dergisi 2/2 (2005) 93-103. 